\title{
Pitched-sound Grammars in the Sharh-iadvar (Commentary to -Eircles") of Abd al-Kadir al-Maragi (1353-1435)
}

\author{
Giula Shamilli \\ Department Theory of Music \\ State Institute for Art Studies \\ Moscow, Russia \\ E-mail: shamilli@gmail.com
}

\begin{abstract}
This article examines Abd al-Kadir ibn Gaybi alHafez al-Maragi's (1353-1435) Sharh-iAdwar (Commentary to "Circles") treatise on music which reflects on the six hundred years of scientific experiences in music theory since al-Farabi up to the beginning of 15 th century. Analyse discovers two description languages of the same pitched-sound system. Both of them depend on the hierarchical and non-hierarchical organization of the structural units, connected with the analytic and synthetic research methods and the genus-species and non-genus-species relations of the basic categories of music theory.
\end{abstract}

Keywords-theory of music; pitched-sound system; logic; structural unit; maqam

\section{INTRODUCTION}

The article is based on the critical editions of the $\mathrm{Ar}$ ic $\mathrm{n}$ Persi $\mathrm{n}$ tre tis es on music inclu ing ' $1-\bar{a}$ ir i $n$ Ġ y $\overline{1}$ 1-Ḥâaez al-M rāĝ̣̀ıs $(1353$ - 1435) treatises [6], [7], [8] n his Š r h-i wār (Comment ry to Circles") which was fragmentarily translated in Russian [14], [15], [16]. I will give a very general outline of the basic idea, remaining in the fiel of theoretic 1 thought out the $r t$ of $m q a \bar{m} n$ $\mathrm{n}$ ly zing the $\breve{\mathrm{S}} \mathrm{rh}$. By stu ying the role of the $\breve{\mathrm{S}} \mathrm{r}$ h through the history of medieval maqam theory, it is possible to understand the two strategies of the organization of the pitched-sound systems in relation to scientific methods and description of the basic music categories. There is the conflict of two scientific metho $s$ in the $\breve{S}$ rh in spite of the similarities of the themes and problems in the Arabic and Persian treatises on music of the 10 th -15 th centuries. And this conflict was dependence on two world pictures of the classical Arabic-Muslim culture (7th - 15th cc.).

Despite the fact that all treatises in genre risalah almusiqaconnects with the practice the art of maqam - the professional music of the oral tradition - there was not one efinition of the term -mqām" in the music theory. Therefore the rticle ims to $\mathrm{rw}$ ttention to $\mathrm{mqa}$ am eh vior's str tegies $\mathrm{n}$ lyzing the music 1 c tegories" description language, which reflects the variety of realizations of fundamental sense-generating procedures (mechanisms) of thinking like part-to-whole and opposition-and-unity relations. If we cannot get the completely description the maqam idiom in the original medieval treatises on music there is reason to understand how the description language of the structural units of maqam was organized in connection with the philosophic systems of that historical period.

The main idea of the article is below in the thesis and five paragraphs after that. Because of above mentioned procedures' action, there is reason to observe two world pictures in the organization of the pitched-sound systems:

- The first is the substance-dependent world picture, which is revealed in the understanding the tone as the substance, which has such accidents as location, movement, time, etc., and determines the hierarchical organization the pitched-sound grammar of musical language;

- The second is the non-substance-dependent or process-dependent world picture, which is revealed in understanding the tone as the timeless process and determines non-hierarchical pitched-sound grammar of musical language;

- Both pitched-sound grammars are discovered in the al-M rāgì̄’s Š rh and seem to be a short history of the development of music theory during six ages of the classical Arabic-Muslim culture.

\section{ABOUT THE ŠARH}

Let us note that al-M rāgīis Š r hareflects on the 600 years of scientific experiences in music theory since al-Fārā $\overline{1}$ up to the eginning of 15 thcentury. M ràgī consistently translates it to Persian and comments on the Arabic text of Ş fī 1-Dīn 'sKitā 1- wār fî 1-Mūsīq (Book of Circles in Music) and at the same time also reveals the views of the scholars on the basic musical science categories such as mūsīqī $\mathrm{n} \dot{\mathrm{g}} \mathrm{m} \quad \mathrm{u} \quad \overline{\mathrm{a}} \mathrm{r}$ etc. Here $\mathrm{y}$ it is possi le to contempl te the $\overline{\bar{S}} \mathrm{rh}$ as the encyclopedia of musictheoretical thought of 10 th -15 th centuries. This work, not without re so $n$ overcomes the ss ertion th $t$ : $\rightarrow$ f the $v$ rious comment ries on the Kitā l- wār y fr the most 
significant is the so-c lle $\breve{\mathrm{S}}$ rh of M w lānā Mu rk Sh h (777/1375)" [21].

The $\breve{\mathrm{S}}$ rhcontains the Introduction (muqaddima), two parts (m qāl ) or $15 \mathrm{ch} \mathrm{p}$ ters (f ṣl) and the fundamental Conclusion (hātim ) [8] of ten ch pters title $\mathrm{F}$ wāi $-\mathrm{i}=\breve{\mathrm{s}} \mathrm{r}$; in fact, independent work was separately copied through the centuries as a stand-alone treatise [3]. Al-M rāḡī `s $\breve{S}$ rh remembers the dramatic pages of the history of the classical Arabic-Muslim culture when the different world pictures clashed to form the contradictory unity. Perhaps a set of different opinions could give rise to see the chaotic way of presenting the information about a subject matter without its strict selection $\mathrm{n}$ or ering in the $\breve{\mathrm{S}} \mathrm{rh}$. However, my investigation started with the first chapter being about the me ning the wor $n$ term -music" (mūsīqī) n reve le that all citation instances have the aim of establishing the truth (h q $\overline{1} q \mathrm{t}$ ) of phenomen to show how ifferent $\mathrm{n} t$ the sme time irreconcil le $r$ e the positions of the uthorities. $1-\bar{a}$ ir's $\mathrm{n}$ lysis of the pre ecessors“ definitions demonstrates how correctly appending a word or short phrase forms a new way of understanding the wellknown definitions.

\section{METHOD AND LOGIC}

Analysis of the basic musical categories coherency in the al-'Urm wī`s itā on the one hn n 1-M rāgīìs Š rhon the other, gives grounds to discuss two research methods in touch with two types of theoretical thought. The first one is the analytic method which has been applied since Ptolemy`s $(100-175$ B.C. $)$ Harmonica and was well known in the E st ern perip tetic philosophy school ( $\bar{u} N$ ş r Muh $\mathrm{m} m$ al-Fārā $\overline{1}(.950) \mathrm{n}$ others) irrespective of acceptance or critics of Pythagoreans cosmology. The second one is the synthetic metho which w s orrowe y Ş fī l-Dīn from the classical theory of Arabic grammar and applied to the description of the pitched-soun system in Kitā . P r ti lly it was supported by al-M rāgīi in the Š r hon the s e of rootrunch" (aṣl-f $\mathrm{r}^{6}$ ) pair for classification and systematization of the difference phenomena [15].

Relative to the Eastern peripatetic philosophy school and non-form lizing logic of Mutzil n theoretical Sufism, there is reason to connect both above-mentioned methods with the logic of su st $n$ ce" $n$ the logic of process" [2 18] forming two types of thinking and the specific description language for each of them. The first type completely reflects the genus-species relationship between the basic categoriesin music theory's description language; it was expressed by al-Fārā $\overline{1}$ in his Gre t Book of Music" (Kitā l-mūsīqī l-k īr) [1]. The secon one reflects the non-genus-species relationships and, to my way of thinking, could be partially considered in the matter of Fakhr al-Dīn 1Rāzī̀s $(1141$ - 1209/10) acoustic theory $[11,12,13]$. At the s me time in Ş fī l-Dīn's coustic theory [20] $\mathrm{n}$ his pitched-sound grammar [19] was not completely supported $\mathrm{y} M$ rāgi $\mathrm{n}$ returne to the irection of the $\mathrm{n}$ ly tic method [8] in the Conclusion of the $\breve{S} \mathrm{r}$ h.

\section{RETURNING TO ANTIQUITY METHOD}

Wht oes returning to ntiqutymetho " me $n$ rel tiv ely to the Š r ḥof ، $\quad 1-\bar{a}$ ir al-M rāgìi? l-M rāgì took Ş fī 1-Dīn's view of the music science su ject inspire $y$ his $r$ ti on le for the tone" $c$ tegory $s$ well as the principle of org $n$ izing the potenti 1 (84 wār) $n$ ctu 1 (12 šu $\overline{\mathrm{u}} \quad 6 \quad \bar{a} w a \bar{z} \mathrm{t})$ soun structures. Expressing admiration and at the same time criticizing his spiritual teacher, Sheikh al-M rāgì i not however opt his metho wholly nor the description language of pitched-sound grammar completely, in which there was no fundamental c tegory such s the gre ter system" $(=\mathrm{j}$ m tāmm; pers. jam-itāmm; perfect system"=j m ' kāmil; pers. j m -ikāmil). This category was explained for the first time in Harmonica of Ptolemy [5] and transformed by al-F rā $\overline{1}$ sKitā 1mūsīqiin correspon ence with the music l pr ctice of Maverannahr where he had lived for approx. 40 years. This greater system provides the hierarchical organization as the guarantor of the order and harmony in the world of sounds. It seems that the lack of a hierarchically organized pitchedsoun system in Kitā is the result of the otherness of Ş $f_{\overline{1}} \quad$ Dīn`s logic not the misun erstanding of the young scientist.

Al-M rā $\bar{g} \overline{1}$ eci es to write the final chapter of the Šrh-eorrecting" S fi 1-Din's -excessively su tle music stu $\mathrm{y}^{\prime \prime}[8] \mathrm{n}$ to solve the theoretic 1 questions $-\mathrm{y}$ the wor s of pre ecessors".

\section{Al-M rāgī writes:}

- s fr s we hve ( lre y) h the solutions to 11 the problems that explain the numerous benefits and excessive su tlety of the stu y of music (in Kitā ) from the M qāșed al-Alhān (cre te e rlier th $\mathrm{n}$ this $\breve{\mathrm{S}}$ rh but later than the $\mathrm{J}$ m 1 -Alhān) using the wor s of our pre ecessors we will expl in the ten = enefits' for knowing the [truth] (șāhebidawq) and the amorousness of the prevailing desire [to it] ( š eqan-e gāle -iš w q) in or er to show how we c n profit from it. I c ll e this ook Z wāi l-F wāi which h s ten ch $\mathrm{p}$ ters" [8]. ${ }^{1}$

Therefore, there is reason to speak about the reconversion

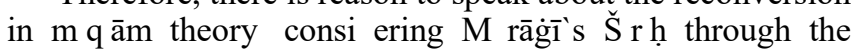
method and description language, not only this treatise. The comparison of two versions of the treatise known as the tre tise on music of Niš pūrī" $\left[\begin{array}{ll}9 & 10\end{array}\right]$ gives reason to conclude that:

- tre tis e on music" $h \quad$ een written in the e rly 14 th century $\mathrm{y}=$ non $^{\text {" }} \mathrm{uthor}$ which w s the ver 1 commentator (muq r r r) of Nīšāpūrī’s ook;

- tre tise on music" is the compen ium n represents the adaptive version of al-Urmavi`s theory for the musical practice of Khorasan and Persian musical terminology to describe the substancedependent world picture and the hierarchical organization of the sound structures. However, this is a topic for a separate study.

Translated from the Persian by G. B. Shamilli. 


\section{Two PITHED-SOUND SYSTEMS}

Abd al-Kā ir not cci ent lly st rte $Z_{w}$ ài with the chapter out Sequencing ( $\mathrm{t} r \mathrm{i} \overline{\mathrm{i}}$ ) of four tetr chor $1 \mathrm{rnks}$ (țabaqat) in the greater system (jam" tāmm)" [8], presenting one in the geometric image of hierarchical integrity of the small and large circles "Fig. 1". The largest one is the double-oct ve interv $1\left(u_{=} 1\right.$-żìkullm $\mathrm{rrt}$ in $)$ cont ining $\mathrm{c}$ cor ing to the $\mathrm{u}$ thor gre te $\mathrm{r}$ system in which there re four qu rts $\left(u_{=} \dot{z} \overline{1} 1\right.$-arba' $)$ and two whole tones $\left(u_{=} \operatorname{t} n \bar{i} n \overline{1}\right) "$ [8]. The gre ter system is ivi e into two $\mathrm{h}$ lves $\mathrm{y}$ the -mtu $1 \mathrm{mi}$ st" ( 1 -wasați 1 -mušt $\mathrm{r} \mathrm{k}$ ) or two oct ves ( $u_{-} \dot{z} \overline{1}$ 1-kull $)$. Each of them contains two tetrachords (jins) and a whole tone that is organically linked

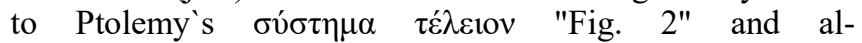
Fārā ì'sj m 'tamm [1] with regard to part-and-whole and opposition-and-unity relations as the fundamental procedures of theoretical thought.

Here we can see the hierarchical paradigm in which (1), the parts are contrary and leaving a gap in-between; and (2), the whole in the case of where its augmentation or reduction remains the sum of its parts in the Aristotelian sense as is possible to see in his Metaphysics:

- whole me ns (1) th t from which is sent none of the parts of which it is said to be naturally a whole, and (2) that which so contains the things it contains that they form a unity; and this in two senses-either as being each severally one single thing or s m king up the unity etween them". 2

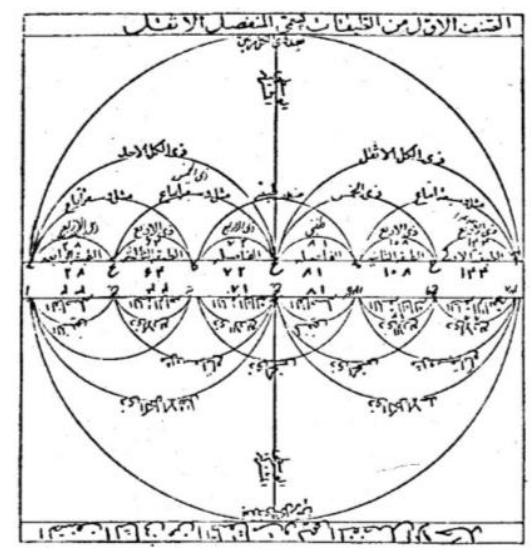

Fig. 1. Gre ter system in the $\breve{S}$ rh.

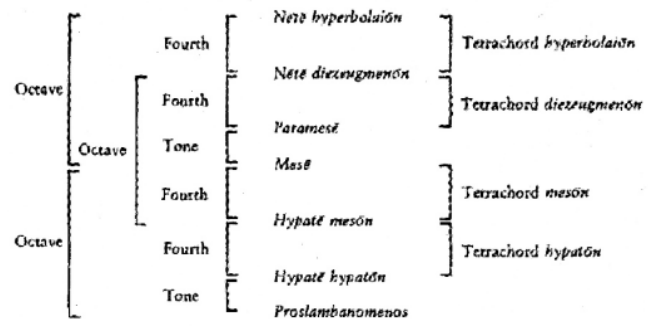

Fig. 2. Ptolemy`s greater system. Translation of Andrew Barker [5].

2 Metaphysics, by Aristotle. Book V.

https://ebooks.adelaide.edu.au /a/aristotle/metaphysics/book5.html.

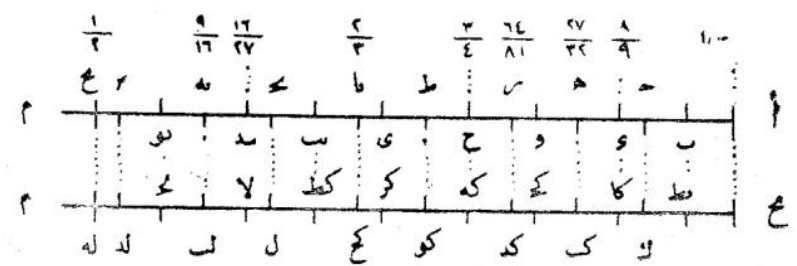

Fig. 3. Pitched-soun system of al-'Urm wī [19].

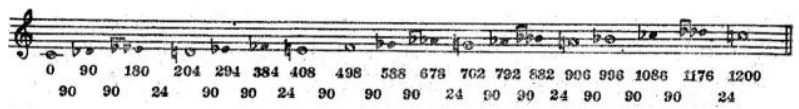

Fig. 4. Transcription of V. M. Belyaev [4].

However, in this case, the greater system includes a number of the features that al-M rāgì oes not consi er. First there re the fixe soun $\mathrm{s}(\varepsilon \dot{\varepsilon} \sigma \varpi \tau \varepsilon \varsigma \nu \theta$ ó $\gamma \gamma \mathrm{ol}=\mathrm{n} \dot{\mathrm{g}} \mathrm{m}$ rāti $\mathrm{h})$ as the boundaries of tetrachords and non-fixed sounds

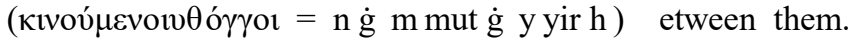
Secon ly it $\mathrm{m}$ es tr $\mathrm{n}$ sition $(\mu \varepsilon \tau \alpha \beta \mathrm{o} \lambda \dot{\eta}=$ 'intiqāl) from one mode to another by means of a common sound or two or three of them.

I see the contradiction arising not because these greater system`s qualities were ignored by al-M rāgī ut ec u se he i not wiver from Ş fī l-Dīn`s system tic principles $n$ even developed them, whereas the notions of order and $\mathrm{h} \mathrm{r}$ mony in Ş f $\overline{1}$ l-Dīn's theory is not associated with the hier r chic 1 org niz tion. On the contr ry Ş fī l-Dīn describes each tone of the pitched-sound system as a rot ti on $x$ is" (m ār) for melo ic structure. l-'Urm w $\overline{1}$ st $r$ ts the secon ch pter of Kità out The ivision of the frets" $y$ the revolution $r y$ thesis which seems $\mathrm{p} \mathrm{r}$ oxic 1 and, in essence, cancels put any possibilities of being able to comment on it as a specific option of greater system "Fig. 3", "Fig. 4".

He writes, The frets (1- sātīn) whose signs re $\mathrm{v}$ il le in the sh kes (s wa $\bar{a}^{\prime} \mathrm{i}$ ) of the string instruments (al-' lātż wāt l-w tār) re the pl ce (m qām) where the process of tones coming into existence (muxārij $1-n \dot{g} \mathrm{~m}$ ) from the parts of the string (ajzah al-watar) comes true. 17 tones, each of which is the axis of rotation for the melodies (m ār 1-alhạan) re loc te on one string" [19 8]. ${ }^{3}$

\begin{tabular}{|c|c|c|c|c|c|c|c|c|c|c|c|c|c|c|c|c|c|c|}
\hline & I & & & II & & & III & IV & & & v & & & $\mathrm{VI}$ & VII & & & vII \\
\hline 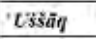 & c & & & D & & & E & $F$ & & & G & & & A & 9 & & & C \\
\hline Navã & C & & & $D$ & $E$ & & & F & & & G & $A$ & & & B' & & & c. \\
\hline Busalik & C & $D^{\prime}$ & & & $\vec{E}$ & & & $\mathrm{~F}$ & G & & & $A^{3}$ & & & B? & & & C \\
\hline Rầst & C & & & D & & $E^{t}$ & & F & & & G & & $\mathrm{A}^{1}$ & & B & & & C \\
\hline Zangulah & c & & & D & & $E^{L}$ & & F & & $G^{1}$ & & & $\mathrm{~A}^{+}$ & & $B^{\prime}$ & & & c \\
\hline Huseint & C & & $D^{1}$ & & E & & & F & & $\mathrm{G}^{+}$ & & $A^{\prime}$ & I & & B & & & c \\
\hline Zirafkand & c & & $D^{4}$ & & $E$ & & & F & & $\mathrm{G}^{2}$ & & $N^{\prime}$ & $A^{4}$ & & & $B^{2}$ & & C \\
\hline Rahavi & C & & $D^{2}$ & & & $E$ & & $\mathrm{~F}$ & & $\mathrm{G}^{\mathrm{t}}$ & & $A^{y}$ & & & B & & & C \\
\hline Isfahān & c & & & D & & $E^{5}$ & & F & & $a^{4}$ & & 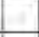 & $A^{4}$ & & B & & $B$ & C \\
\hline Hijazit & c & & $D^{f}$ & & E & & & E & & $\sigma^{1}$ & & & $\mathrm{~A}^{\mathrm{l}}$ & & B & & & C \\
\hline "Arạ̣̄ & c & & $D^{2}$ & & & $E^{*}$ & & F & & $G^{1}$ & & & $\mathrm{~A}^{+}$ & & $B^{\prime}$ & & $B$ & c \\
\hline Butzurg & c & & $D^{2}$ & & & E & & F & & $\mathrm{G}^{1}$ & G & & & $A$ & & $B^{t}$ & & C \\
\hline
\end{tabular}

Fig. 5. 12 šu $\overline{\mathrm{u}}$ : the «root- runch» ("ṣl- $\mathrm{f} \mathrm{r}$ ) rel tion (table by Shamilli).

\footnotetext{
Translated from the Arabic and Persian by G. Shamilli.
} 
Studying the question of why every tone of the 17-tone sc le is the rot tion $\mathrm{x}$ is" ( $\mathrm{m} \overline{\mathrm{a}} \mathrm{r}$ ) or the pill $\mathrm{r}$ tone of the melo ies reve le th $\mathrm{t} S \mathrm{~S} \mathrm{f}_{\overline{1}}$ l-Dīn escri es the paradigmatic system or a mathematical set of one-level system elements which are not hierarchical. The main point is that the tone as the unit of pitch-sound grammar is described not as a substance, occupying an equal place, but a process, or logical relationship (nisbat) of two sounds ("swāt) in the tone ctully equ 1 to the interv 1 . There $y$ all sound structures such as interval, tetrachord, pentachord and octave scale are described as transformations; only one unit of pitch-sound, grammar-tone in such states as the compositing" (tā'lif) -eonnection" (j m $) \quad n$ eonjunction" (izāa ) where the tone is the p rt of pe rl neckl c e" (ş $) \mathrm{n}$ equ 1 to the whole ut ş (= m q ām) is the fullness of all these states. Thus, the coherence of the sic c tegories in Şf $\overline{1}$ l-Dīn's escription $\operatorname{lnguge}$ is fundamentally different in contrast with its predecessors and which considers each sound structure substance dependently as an autonomic part of the whole.

This is extremely important in understanding the functions of the basic structures (12 šu $\overline{\mathrm{u}} ; 12 \mathrm{mq} \bar{a} \mathrm{~m}$ tin [17]) and their internal links. Abd al- $\bar{a}$ ir discusses them, commenting on the ninth chpter of Ş fī l-Dīn`s Kitā - out the $\mathrm{nmes}$ of the f mous sc les" consi ering the terminological inconsistencies in the arguments of al'Urm wī n his successor Qut -Dīn 1-Širāzī (12361311).

\section{Al-M rāgīi writes:}

This nee ing [in Go ] and insignificant [to Him], comparing their works, so will judge and explain [below] all rel te with them. In $\mathrm{c} \mathrm{t}$ the term $\mathrm{p} \mathrm{r}$ ' in the [voc ul ry of] musician-pr ctitioners is the $12 \mathrm{sc}$ les ( wāîr) s st te

ove: they c 11 the $12 \mathrm{~m} \mathrm{q} \mathrm{am}^{\text {' }} \mathrm{y}$ the term $\mathrm{p} \mathrm{r}$ '. The 12 sc les were selecte ("intixā ) n correcte (mun q q ha) from the 91 sc les $n$ were c lle y 12 sc les ( āīr) s st te ove. These $12 \mathrm{sc}$ les ( $\bar{a} \bar{i}$ ) took pl ce un ou te ly in his own root' ('s șl). Well-known to all people (maşhūr) sc les ( wā̄r) c tu lly re c lle the roots' ('ușūl) n the $=\mathrm{rnch}^{\text {‘ }}$ (furū $)$. The roots' of $12 \mathrm{~m}$ q ām t re Uššāq Rāst Husein̄i n Hij zī ec u se 'Uššāq is root' for Bus lik n $\mathrm{N} v \bar{a}$. Nvā n Bus lik re loc te $\mathrm{t}$ [his pitch] centers (m rākiz) $\mathrm{n}$ the tetr chor $1 \mathrm{rnks}$ of Ušša $\mathrm{re}$ re 1 . $\mathrm{Zngul}$ is inclu e in Rāst $\mathrm{n}$ Zirfkn $\mathrm{Rh} \bar{a} \overline{\mathrm{i}} \mathrm{n}$ Hus in $\overline{1}$ in Isf $h \bar{a}$ lthough the interv 1 of sm ll semitones ( qiyy) in the Hus in $\overline{1}$ is ppers ut other tones re inclu e. Some tones of $\mathrm{R} h \overline{\mathrm{a}} \mathrm{v} \overline{1}$ re in Zangula, while others re in Hijāz rāq n Buzurg" [8].

Thus, unlike the greater system, there is absolutely other part-and-whole reltionship in the root- $\mathrm{rn} \mathrm{ch}^{*}$ systematization of $12 \breve{s} \mathrm{u} \overline{\mathrm{u}}$. We c n see the results of the analysis in the table (Fig. 5). Transition from one structure to another is possible with the mutation from one to four elements (tones) of the sic structure (root') ut other elements are the same.

\footnotetext{
4 Translated from Persian by G. Shamilli.
}

In the case of the non-hierarchical paradigm, (1) the parts are not contrary, (2) have an indissoluble connection, and (3) the whole in the case of its augmentation or reduction is destroyed. I see this as the opposite way to the greater system`s mode relations.

\section{CONCLUSION}

Investig tions of $\mathrm{mq}$ ām theory $\mathrm{n}$ pr ctice discovers two paradigms in the pitched-sound system's description language. The first one is the hierarchical organization of the structural units, connected with the analytic research method and the genus-species relations of the basic categories (Eastern peripatetic school). The second one is the nonhierarchical organization of the units, connected with the synthetic method and the non-genus-species relations of the basic categories (al-'Urmāvī). There y the -system tics" school (al-'Urmāvī 1-M rāḡì and al-Širāzī) c nnot e considered as a unified theory from this method's point of view: the contradictions are evident not only between, but also in the theory of each of these scientists. Despite the fact that all theories use the same set of basic categories, the connectivity one is not the same and depends on the type of theoretical thought - su st n ce-dependent or processdependent as was considered above in the case of alM rāgīis Š rh. Reconversion" rel tive to $\mathrm{m} q \mathrm{q}$ àm theory denotes returning to the hierarchical paradigm from al'Urm vī's Kitā 1- wār where the process-dependent worl picture ws est lish together with the root- $\mathrm{rnch}$ " method of classical Arabic-Muslim culture. But, in fact, it i not return to the foreign" investig tion w ys of music realities, having a formal therefore contradictory character, ec use two eh viour's str tegies of $\mathrm{mqa}$ ām $\mathrm{s}$ the worl picture re $\mathrm{n}$ tur lly from $\mathrm{m} q \overline{\mathrm{a}} \mathrm{m}$ tr itions from $\mathrm{M}$ ghre to the boundaries of China. I hope to confirm this inference by analyzing the melodic lines and principle of modulation in ifferent $\mathrm{m}$ qām genres in my next rticle.

\section{REFERENCES}

[1] ū N sr Fārā ̄̄. Kitā 1-mūsīqī 1-k īre" = [Gr n Book of Music. Reproduced from MS 953] Köprülü Kütüphanesi, Istanbul. Edited by Eckhard Neubauer. Frankfurt am Main: Institute for the History of Arabic-Islamic Science at the Johann Wolfgang Goethe University. 1998.

[2] Sc ttere ' $\mathrm{n}$ collecte ': cognitive principles of $\mathrm{r}$-Muslim culture: collective monograph. Moscow: Languages of Slavic cultures, 2017. (In Russian) [- $\underline{\underline{R}}$ ssyp nnoe $\mathrm{i}$ so $\mathrm{r}$ nnoe': str tegii organizacii smyslovogo prostranstva $\mathrm{v}$ arabo-musul'manskoj kul'ture: kollektivn y monogr fiy ". Moskv : Y zyki sl vy nskih kul'tur 2015.]

[3] S. H. Agaeva. Encyclope i of zer ij ni mugh m”. B ku 2012. (In Russian) [S. H. g ev Enciklope iy zer j zh nskogo mug $\mathrm{m}$ ". B ku 2012].

[4] V. Belyaev. - out music 1 folclore $n$ ncient liter ture". Moscow 1971. (In Russian) [V. Bely ev $\bigoplus$ muzyk l'nom fol'klore I revnej pis'mennosti”. Moskv 1971.]

[5] Greek Music 1 Writings", Vol. II. H rmonic n acoustic theory". Edited by Andrew Barker. Cambridge - New York: Cambridge University Press, 2004.

[6] al- ir i n G i i 1-Mar gi. Đestin tion of the melo ies". Tehr n 1966. (In Persian) $\left[{ }_{\bar{c}}\right.$ al- $\bar{a}$ ir i n Ġ i $\overline{1}$ 1-Marāgì M qāsi al-alhạan". Tihrān 196̄ 6.$]$ 
[7] al- ir i n G i i 1-Mar gi. -Eillection of the melodies". E . yT ki Binish.Tehr $n$ 1987. (In Persian) ${ }_{-} \quad$ al- $\bar{a}$ ir i n Gं i $\overline{1}$ al-Marāg̀ì Jam“ al-alhạān”. Be ihtimām-i T kī Bīniš. Tihrān 1987].

[8] al- ir i n G i i 1-Mar gi. -Comment ry to Circles"”. E . yT ki Binish.Tehr n 1991. (In Persian) $\left[L_{-}\right.$al- $\overline{\bar{a}}$ ir i n $\dot{G}$ i $\overline{1}$ al-Marāàì $\breve{S}$ rḥ-i wār". Be ihtimām-i T kī Bīniš. Tihrān 1991].

[9] Muhamma i n Mahmu Nish puri "Book of musical science"/ u al-M j Muhh mm i n M su= $\mathrm{T}$ rizi. S fineh-i Tabriz: $a$ tre sury of Persi $\mathrm{n}$ liter ture. Tehr $\mathrm{n}$ University Press 2001. Pp. 4326 - 433a. (F csimile of $\mathrm{m}$ nuscript)]. (In Persian) [Muḥamma i $\mathrm{n}$

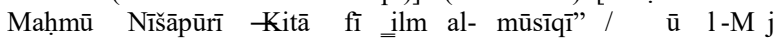
Muh $\mathrm{mm}$ i n M su= $\mathrm{T}$ rizī. S fineh-i Tabriz: a treasury of Persian literature. Tehran University Press 2001. Pp. 4326-433a. (Facsimile of manuscript)].

[10] Muhamma i n Mahmu Nish puri. "Science of music". RF-IOM, C- 612, pp. 27 b-28 b. (Manuscript) (In Persian) [Muḥamma i n Maḥmū Nīšāpūrī Illm-i mūsīqī. RF-IOM C- 612, pp. 27 b-28 b. (Manuscript)].

[11] Fahraddin Razi. Illm 1- mūsīqī Music cognition‘. Persi n tr nsl tion and commentary by G. B. Samilli // Ishraq: Islamic Philosophy Ye r ook № 4, 2013. Moscow: Nauka- Vostochnaya literatura, pp. 596-609. (In Russian) [F hr in R zi Ilm l-m sū «Pozn nie muzyki». Perevod s persidskogo I kommentarij G. B. Samilli // Ishrak: ezhego nik isl mskoj filosofii № 4 2013. Moskv : N uk Vostochnaya literatura, pp. 596-609].

[12] Fahr a -Din Rāzi. Eollection of the science”. T shkent [ . g.] pp. 371-378. (Litogr fiy ). (In Persian) [Fahr ad-Dīn Rāzī $\mathrm{J}_{\mathrm{mi}}=1-$ ulūm". T shkent [ . g.] pp. 371-378. (Litografiya)].

[13] Fahr a -Din Rāzi. - Eollection of the science". M nuscript of İr-KMT, № 813785 pp. 337-344. (In Persian) [Fahr a -Dīn Rāzī Jami_alulūm”. M nuscript of İr-KMT № 813785 pp. 337-344].

[14] G. B. Shamilli. - 1-Kadir Maragi: Sharh-i v r. commentary to circles'. Tr nsl tion of the first $\mathrm{Ch}$ pter of the treatise from Persian and Arabic by G. B. Shamilli and A. V. Smirnov.Preface and comment ry y G. B. Sh milli” / / Ir no-Sl vik 2006 №1 pp. 9-12. (In Russian) [. B. Sh milli - 1-Kadir Maragi: Sharhi v r. Komment rij k Krug m' - Perevo pervoj glavy traktata s persidskogo I arabskogo G. B. Shamilli iA.V.Smirnova. Predislovie ikommentarij G. B.Shamilli / Irano-S1 vik 2006 №1 pp. 9-12].

[15] G. B. Shamill. $-\mathrm{Cl}$ ssic 1 music of Iran: the fundamental categories of the theory $\mathrm{n}$ pr ctice". M.: State institute for Art Studies, 2009. (In Russian) [G. B. Shamilli. Kl ssichesk y muzyk Ir n : fun ment l'nye k tegorii teorii I pr ktiki”. Rukopis' issert cii $\mathrm{n}$ soisk ... oktor iskusstvove eniy . M.: Gosu rstvennyj institute iskusstvoznaniya, 2009].

[16] G. B. Shamilli. Cl ssic 1 music of Iran:rules of knowledge and practice. (In Russian) [G. B. Sh milli -K1 ssichesk y muzyk Ir n : pr vil pozn niy I pr ktiki". M.: Kompozitor 2007].

[17] Qutb ad-Din Shirazi. The Pe rls of the Crown". V. I. E . M. Mishkat. Tehr n 1938. ( In Persian) [Qutb ad-Din Širāzī Đurr t 1-tāj li-gururr t al- āj”. V. I. E . M. Mišk t. Tihrān 1938].

[18] A. Smirnov. $+\mathrm{n}$ Kh 1 ūn $\mathrm{n}$ his New Science، " / Isl mic Philosophy Yearbook, No. 5. Moscow: Vostochnaya literature, 2014. Pp. 217-237.

[19] Safi al-Din Urmawi. "Book of circles‘. K iro 1986". (In Arabic) [Ṣ fì l-Dīn Urmwī Kitā al- wār fì m_rif al-nag̀ m y alwār". K iro 1986].

[20] Safi al-Din Urmawi. Fre tise in the dedication of sharaf [al-Din]". Tehran, 2005. (Facsimiletext) (In Persian) [S fì 1-Dīn Urm wi Risāl šar fiyy . Be hațt Ș fì 1-Dīn Urm vī: mūsīqī ān-i qorn-i h ftom h. q.". Tihrān 2005].

[21] Wright O. Mūsī ì (mūsī )" extr ct from the Encyclop e i of Islam CD-ROM Edition v. 1.0. Leiden: Brill, 1999. 